\title{
PENGANTAR REDAKSI
}

Sidang redaksi Jurnal Profetika pada edisi ini menerbitkan Vol. 21, No 1, Juni 2020, dengan mengangkat beragam karya tulis ilmiah kajian keislaman dari berbagai kalangan baik dari pakar maupun akademisi. Pembahasan pada edisi ini juga mencakup multidisiplin ilmu keislaman, baik pemikiran Islam, pendidikan Islam, hukum Islam, hukum ekonomi Islam, studi ilmu al-Qur'an, dan studi ilmu bahasa Arab. Berbagai disiplin kajian tersebut telah mendapatkan perhatian yang serius demi terwujudnya pemahaman dan pencerahan yang dinamis demi kemajuan studi Islam di Indonesia.

Dimulai dengan artikel yang ditulis oleh Kurniawan Dwi Saputra, yang mengangkat judul Paradigma Liberal Arts Dalam Pendidikan Di Era Disrupsi: Studi Kasus di Zaytuna College, hasil penelitian ini berargumen bahwa pendidikan liberal arts selaras dengan prinsip-prinsip pokok pendidikan Islam yang memandang manusia sebagai makhluk holistik dengan potensi yang beragam.

Kedua penelitian berjudul pembelajaran materi PAI berwawasan moderat, yang ditulis oleh Muhlis ini mengangkat persoalan beberapa institusi pendidikan sering tidak disadari telah melahirkan peserta didik / siswa yang memiliki sikap menutup diri dari kebenaran yang disampaikan oleh pihak lain, kecenderungan kepada pemahaman dan sikap ekstrim. Konsep Pendidikan Agama Islam (PAI) berwawasan moderat hadir untuk mengatasi hal tersebut. Sehingga dalam memahami nilai-nilai pokok multikultural mulai dari sikap inklusif terhadap perbedaan-perbedaan, menghormati, demokrasi, toleransi, menghargai hasil karya orang lain, sikap mengutamakan persatuan dan kesatuan dalam suatu komunitas atau masyarakat yang berbeda latar belakang suku, budaya, bahasa, agama, dan lain-lain, sehingga pada akhirnya siswa diharapkan mampu mempraktekkan sikap-sikap tersebut dalam kehidupan seharihari.

Ketiga tentang Bermuhammadiyah Melalui Spiritual Amal Saleh Filantropi Cilik Lazismu: Literatur Fungsi Bahasa, yang ditulis oleh Marwanto. Hasil dari penelitiannya menyimpulkan bahwa direktur, kepala sekolah dan para guru bersinergi mendukung dan memberikan suport kepada siswa terhadap filantropi cilik Lazismu ini, siswa juga menyambut dengan baik pelaksanaan filantropi ini, bahkan mendapat dukungan pula dari orang tua mereka.

Keempat, tentang Kontribusi Dan Tipologi Pemikiran Hadis Muhammad Dailamy Dalam Bidang Hadis Di Jawa Tengah, oleh Diyan Faturahman dan Nur Kholis. Menurutnya penelitian tentang tokoh hadis belum banyak dilakukan, padahal kontribusi mereka dalam menjaga dan melestarikan sumber hukum Islam yang kedua ini sangat banyak. Oleh karena itu Muhammad Dailamy yang merupakan salah satu tokoh hadis yang cukup berpengaruh di Jawa Tengah akan diungkap kontribusi dan tipologi pemikiran hadisnya.

Kelima yang ditulis oleh Dzaky Adam Thamrin, Boby Habibi, Dewi Permata Sari, dan Fauzul Hanif Noor Athief, tentang Analisis Strategi Islamic Collective Entrepreneurship (Ice): Solusi Mengatasi Desa Tertinggal. Hasil penelitian menyimpulkan bahwa strategi ICE yang dilakukan Desa Gerdu memiliki 3 (tiga) tahap yaitu: 1. Pendidikan dan Kerjasama, 2. Pelaksanaan dan Pengelolaan, 3. Evaluasi dan Perencanaan. Selain itu, faktor pendorong internal dalam kesuksesan ICE terletak pada keaktifan pemuka dan pemuda desa dalam mempraktikkan ekonomi Islam. Adapun kerjasama dengan pihak eksternal seperti BAZNAS, DISPARPORA, serta lembaga lainnya sekitar desa yang aktif membantu dalam pembangunan desa. 
Keenam tentang studi al-Qur'an. Studi ini mengangkat tema Manuskrip Mushaf al-Qur'An Daun Lontar Koleksi Kiai Abdurrochim (Kajian Pemakaian Rasm Dan Qira 'At), yang ditulis oleh Qona'ah Dwi Hastuti Dan Moh. Abdul Kholiq Hasan. Hasil penelitian menemukan bahwa mushaf tersebut dalam penulisan rasm menggunakan kaidah rasm usmani, meskipun ada beberapa kesalahan dalam penulisan namun tidak mempengaruhi tulisan tersebut. Sedangkan pada aspek qira'at mushaf tersebut menggunakan qira at Imam Ashim riwayat Hafs dalam menyalin teksnya. Meskipun ada beberapa kata dalam lafal-lafal tertentu yang masih merujuk pada qira'at Qalun riwayat Nafi'.

ketujuh dan kedelapan masih tentang studi al-Qur'an, berjudul Manajemen Pembelajaran Tahfizh Al-Qur'an di Pesantren Al-Kahfi Surakarta dan Pesantren Nurul Iman Karanganyar, yang Ditulis Oleh Hamzah Kamaludin, Syamsul Hidayat, dan Mohamad Ali. Serta tema tentang al-Qur'an lainnya berjudul Implementasi Pembelajaran Al-Qur'an Metode Littaqwa Di Sdit Nur Hidayah Surakarta Dan Metode Karimah Di Mi Nurul Karim Karanganyar, penelitian yang ditulis oleh Bayu Mufti Sugiyanto, Ari Anshori, dan Muthoifin ini menyimpulkan bahwa target utama pembelajaran al-Qur'an di SDIT Nur Hidayah adalah pemahaman tentang kaidah ilmu tajwid dengan target hafalan minimal 2 juz (juz 29 dan 30) dan hafalan hadits, metode pembelajaran yang digunakan adalah littaqwa dengan menerapkan tiga model pembelajaran yaitu klasikal bersama guru, klasikal mandiri dan klasikal satu-satu. Evaluasi dilakukan setiap akhir pertemuan dan evaluasi kenaikan jilid. Sedangkan di MI Nurul Karim target hafalan yang dimiliki oleh lulusannya \pm 5 juz (juz 26, 27, 28, 29 dan 30), pembelajaran menggunakan metode karimah yang mempunyai empat prinsip pengajaran yaitu talqin, tikrar, tahqiq dan tabyin. Evaluasi pembelajaran dilakukan dengan 3 tahap yaitu ujian kelas, juziyyah dan puncaknya adalah ujian juara umum terbaik tahfidz sekolah. Implemetasi pembelajaran al-qu'an telah menerapkan pendekatan kontruktivisme dalam memilih strategi pembelajaran, sebagai upaya menciptakan proses pembelajaran yang sesuai dengan karakter peserta didik.

Kesembilan penelitian berbahasa Arab dengan judul ditulis oleh Fajar Rachmadhani. Dan yang kesepuluh juga penelitian berbahasa Arab yang ditulis oleh Nuha dan M. Syakirin Ghozaly yang berjudul القيمة التربوية في كتاب المحفوظات الموضوعية عن العلم والأب لإبن عارف tujuan dari penelitian ini adalah untuk mengetahui gambaran umum dari buku mahfudzat tematik bunga rampai peribahasa Arab ilmu dan adab karya ibnu arief, serta mengetahui nilai-nilai pendidikan yang ada dalam buku tersebut. Hasil penelitiannya adalah gambaran umum dari kitab mahfudzat karya ibn arif adalah bahwa isi kitab mahfudzat ini meliputi al-hadits dan atsar sahabat, bait-bait hikmah, nasehat ulama' dan para pujangga. Isi pembahasan dalam kitab ini diawali dengan tema besar nasihat untuk para guru, dipertengahan buku dibahas tentang berbagai macam peribahasa arab mahfudzat dan faidahnya, dan diakhiri dengan latihan-latihan soal. Inti dari pembahasan mahfudzat dalam buku ini terdiri dari $3 \mathrm{bab}$. Bab pertama membahas tentang ilmu, bab kedua tentang adab, bab ketiga tentang adab. Jumlah keseluruhan mahfudzat yang ada dalam buku tersebut berjumlah 92 buah. Sedangkan nilai-nilai pendidikan yang ada dalam kitab mahfudzat ini secara maknawi mengandung 5 (lima) aspek pendidikan, yaitu: pendidikan iman, ilmu, amal, akhlak, dan sosial.

Akhirnya, segenap tim redaktur berharap Profetika Vol. 21, No 1, Juni 2020 ini dapat memberikan sumbangsih yang mencerahkan kepada para pembaca dan masyarakat pada umumnya dalam memahami berbagai perkembangan wacana dan 
Pengantar Redaksi

dinamika Islam, utamanya yang terkait langsung dengan tema-tema yang dimuat dalam jurnal ini.

Redaksi 